\title{
A Facile Synthesis of Highly Nitrogen-Doped Carbon Dots for Imaging and Detection in Biological Samples
}

\author{
Qianchun Zhang ${ }^{D}$, Siqi Xie, Yanqun Yang, Yun Wu, Xingyi Wang, Jincheng Wu, \\ Li Zhang, Junyu Chen, and Yuan Wang \\ School of Biology and Chemistry, Xingyi Normal University for Nationalities, Xingyi 562400, China \\ Correspondence should be addressed to Qianchun Zhang; qianchunzhang@qq.com and Yuan Wang; 45001490@qq.com
}

Received 21 March 2018; Accepted 17 May 2018; Published 15 July 2018

Academic Editor: Subhankar Singha

Copyright (C) 2018 Qianchun Zhang et al. This is an open access article distributed under the Creative Commons Attribution License, which permits unrestricted use, distribution, and reproduction in any medium, provided the original work is properly cited.

\begin{abstract}
A facile, green, and high-output hydrothermal synthesis was proposed for the fabrication of highly fluorescent nitrogen-doped carbon quantum dots ( $\mathrm{N}$-doped CDs). The nitrogen content in $\mathrm{N}$-doped $\mathrm{CDs}$ reached $19.2 \%$ and demonstrated strong blue fluorescence emission was obtained with fluorescence quantum yield (QY) of up to 32.9\%, which exhibit high fluorescence quantum yield, high photostability, and excellent biocompatibility. The N-doped CDs possess high photostability, low toxicity, and excellent biocompatibility, based on which the N-doped CDs were successfully applied as a fluorescence probe for cell imaging. Moreover, it was then successfully demonstrated for sensitive and selective detection of $\mathrm{Fe}^{3+}$ in serum.
\end{abstract}

\section{Introduction}

During the past few years, fluorescent CDs have attracted tremendous attention due to their unique optical and electronic properties [1-6]. Compared to conventional semiconductor quantum dots and organic fluorescent dyes, CDs possess several superior features including functionalization, low toxicity, excellent water dispersibility, tunable fluorescence emission, excellent photostability, upconversion, and biocompatibility, thus demonstrating potential application in the fields of bioimaging, in vivo theranostics, drug delivery, light-emitting diodes, photocatalysis solar cells, and heavy metal ion detection [7-11]. In addition, doping CDs with other nonmetallic components, such as $\mathrm{N}$, $\mathrm{S}$, and $\mathrm{P}$, can inject electrons into carbon-based materials and change the electronic transport properties and $\mathrm{PL}$ properties $[12,13]$. However, in most cases, the QY of the assynthesized CD was less than $10 \%$, and the QY is a key parameter to evaluate the quality of CDs, which limit the sensitivity and selectivity. So, synthesis of high-fluorescence carbon quantum dots is the direction of development.

The use of $\mathrm{N}$-containing precursors has proved to be an effective route for obtaining N-doped CDs. Chen et al. [14] used 2-azidoimidazole as precursor in a hydrothermal process at $70^{\circ} \mathrm{C}$ overnight to obtain nitrogen-rich CDs. $\mathrm{Lv}$ et al. [15] using ethanediamine and citric acid as precursors obtained $\mathrm{N}$-doped CDs and achieved good results in iron detection. Wang and Zhou. [16] used milk to prepare N-CDs hydrothermally at $180^{\circ} \mathrm{C}$ for $2 \mathrm{~h}$. In another study, Hsu and Chang [17] found that compounds containing both amino and carboxyl groups are beneficial for synthesizing CDs with high PL quantum yield. Based on the benefits of $\mathrm{N}$-doping in carbon nanostructures, it can be extrapolated that the introduction of $\mathrm{N}$ to carbon dots would further enhance their versatile properties. However, most $\mathrm{N}$-doped $\mathrm{CDs}$ are unsatisfactory due to harsh synthetic conditions and long reaction times. Thus, a time-saving and eco-friendly synthesis of $\mathrm{N}$-doped CDs is of interest.

Herein, a facile, green, and high-output thermal strategy is proposed for the fabrication of highly fluorescent $\mathrm{N}$-doped CDs. We used L-citrulline as the precursor for a facile and eco-friendly one-step hydrothermal method without the assistance of any chemicals (except pure water) to obtain highly fluorescent $\mathrm{N}$-doped CDs. The as-prepared N-doped CDs exhibit good water solubility, good biocompatibility, and high fluorescence quantum yield (32.9\%). Owing to the unique properties of the $\mathrm{N}$-doped $\mathrm{CD}$ nanoprobe with good membrane permeability and excellent biocompatibility, it 
was used for imaging of HeLa cells with high discrimination. Moreover, it was further applicated for detection of $\mathrm{Fe}^{3+}$ ions in serum, and the fluorescence intensity exhibited a good linear relationship in the $\mathrm{Fe}^{3+}$ concentration range from 0 to $50 \mu \mathrm{M}$ with a detection limit of about $37 \mathrm{nM}$.

\section{Experimental}

2.1. Materials. L-citrulline (98\%) and quinine sulphate (98\%) were purchased from J\&K Scientific Inc. (Beijing, China). 3(4,5-Dimethylthiazol-2-yl)-2, 5-diphenyltetrazolium bromide (MTT, 98\%) was obtained from Sangon Biotechnology Inc. (Shanghai, China). Dimethyl sulphoxide (DMSO) was obtained from Xilong Reagents Company (Guangdong, China). Penicillinstreptomycin, Dulbecco's modified Eagle's medium (DMEM), and foetal bovine serum (FBS) were purchased from Solarbio (Beijing, China). $\mathrm{NaCl}, \mathrm{KCl}, \mathrm{MgCl}_{2}, \mathrm{AlCl}_{3}, \mathrm{CaCl}_{2}, \mathrm{Cr}\left(\mathrm{NO}_{3}\right)_{3}$, $\mathrm{FeCl}_{2}, \mathrm{FeCl}_{3}, \mathrm{Co}\left(\mathrm{NO}_{3}\right)_{2}, \mathrm{CuSO}_{4}, \mathrm{ZnCl}_{2}, \mathrm{Cd}\left(\mathrm{NO}_{3}\right)_{2}, \mathrm{SrCl}_{2}$, and $\mathrm{Hg}\left(\mathrm{NO}_{3}\right)_{2}$ were purchased from Aladdin (Shanghai, China). HeLa cell lines were obtained from Cellcook. Human serum samples were provided by Xing Ying People's Hospital Blood Center (Xingyi, China). Ultrapure water (18.2 M $\Omega$, Millipore Co., USA) was used in all experiments. Other chemical reagents (analytical grade) were purchased from Beijing Chemical Company (Beijing, China).

2.2. Instrumentation and Characterization. The morphologies and sizes of $\mathrm{N}$-doped CDs were characterized by highresolution transmission electron microscopy (HRTEM, Hitachi-F20) at an accelerating voltage of $200 \mathrm{kV}$ and atomic force microscopy (AMF, Bruker Multimode 8) in the tapping mode. Fourier transform infrared (FT-IR) spectra were obtained on a Nicolet 6700 FT-IR spectrometer using $\mathrm{KBr}$ pellets. $\mathrm{X}$-ray photoelectron spectroscopy (XPS) was performed using an ESCALAB 250Xi (Thermo Scientific). X-ray diffraction (XRD) was carried out using a Rigaku diffractometer in the $2 \theta$ range $10-80^{\circ}$ with step width of $0.02^{\circ}$. UV-Vis absorption spectra were recorded on a DU $800 \mathrm{UV}$-Vis spectrophotometer. The PL decay curves were obtained on a Leica SP5 FLIM system using a $405 \mathrm{~nm}$ laser excitation source. Fluorescence spectroscopy and stability were measured on a PerkinElmer LS 55 with $5 / 5 \mathrm{~nm}$ slit width and equipped with a $1 \mathrm{~cm}$ quartz cell. A TGL-20LM-B high-speed refrigerated centrifuge (Hunan Xingke Instrument Co., Ltd., China) was used to purify the $\mathrm{N}$-doped CDs. Cell imaging was carried out using a Leica SP8 confocal laser scanning microscope (Leica, Germany).

2.3. Synthesis of N-Doped CDs. N-doped CDs were synthesized by a facile hydrothermal method. Briefly, $0.50 \mathrm{~g}$.Lcitrulline was dissolved in $25 \mathrm{~mL}$ ultrapure water and subjected to ultrasonic oscillation for $20 \mathrm{~min}$. The solution was transferred to a Teflon-equipped stainless steel autoclave and reacted at $220^{\circ} \mathrm{C}$ for $12 \mathrm{~h}$. After the reaction liquid was cooled to room temperature, the reaction liquid was centrifuged at $17,000 \mathrm{rpm}$ for $40 \mathrm{~min}$ to separate aggregated particles. The supernatant fluid was removed by filtration with a $0.22 \mu \mathrm{m}$ filter membrane. The as-prepared $\mathrm{N}$-doped $\mathrm{CD}$ solution was stored at $4^{\circ} \mathrm{C}$ for further use.
2.4. MTT Assay and Intracellular Fluorescence Imaging. Cytotoxicity of the $\mathrm{N}$-doped $\mathrm{CDs}$ was investigated with the cancer cell line HeLa by an MTT assay. HeLa cells were seeded in a 96-well plate at a density of $4 \times 10^{3}$ cells per well for $24 \mathrm{~h}$ in an incubator $\left(37^{\circ} \mathrm{C}, 5 \% \mathrm{CO}_{2}\right)$. The culture medium was replaced with $100 \mu \mathrm{L}$ fresh DMEM containing the $\mathrm{N}$-doped CDs at concentrations of $0,25,50,100,250$, and $500 \mu \mathrm{g} / \mathrm{mL}$ and incubated in an incubator $\left(37^{\circ} \mathrm{C}, 5 \% \mathrm{CO}_{2}\right)$. After 24 or $48 \mathrm{~h}, 20 \mu \mathrm{L}$ MTT $(5 \mathrm{mg} / \mathrm{mL})$ solution was added to each cell well, which was incubated for $4 \mathrm{~h}$. Subsequently, the culture medium with MTT was removed and $100 \mu \mathrm{L}$ DMSO was added, followed by shaking for $10 \mathrm{~min}$. The optical density (OD) of each well at $490 \mathrm{~nm}$ was measured on the enzyme-linked immunosorbent detector.

HeLa cells $\left(1 \times 10^{5}\right.$ cells/dish $)$ were seeded in a confocal dish with $100 \mu \mathrm{L}$ fresh DMEM containing 10\% FBS and incubated in an incubator $\left(37^{\circ} \mathrm{C}, 5 \% \mathrm{CO}_{2}\right)$. After $24 \mathrm{~h}$, the $\mathrm{N}$-doped CDs with concentrations of 50, 200, 400, and $600 \mu \mathrm{g} / \mathrm{mL}$ were added to the confocal dish and incubated at $37^{\circ} \mathrm{C}$ in $5 \% \mathrm{CO}_{2}$ for another $4 \mathrm{~h}$. Subsequently, the adherent cells were carefully washed three times with PBS $(0.01 \mathrm{M}$, $\mathrm{pH}$ 7.4). Finally, the laser confocal microscopy imaging of HeLa cells was performed at excitations of 405 and $488 \mathrm{~nm}$. Bright-field images were captured to ensure the locations of fluorescent tag signals.

2.5. Metal Ion Detection by N-Doped CDs. Sources of various metal ions such as $\mathrm{Na}^{+}, \mathrm{Mg}^{2+}, \mathrm{Al}^{3+}, \mathrm{Ca}^{2+}, \mathrm{Cr}^{3+}, \mathrm{Fe}^{2+}, \mathrm{Fe}^{3+}$, $\mathrm{Co}^{2+}, \mathrm{Cu}^{2+}, \mathrm{Zn}^{2+}, \mathrm{Cd}^{2+}, \mathrm{Sr}^{2+}, \mathrm{K}^{+}$, and $\mathrm{Hg}^{2+}$ were applied for detection. N-doped CD stock solution $(2.0 \mathrm{mg} / \mathrm{mL}, 250 \mu \mathrm{L})$ was mixed with $50 \mu \mathrm{L}$ of $120 \mu \mathrm{M}$ solutions of different metal ions to reach the final concentration of $20 \mu \mathrm{M}$, respectively. Afterward, the mixtures were recorded under excitation at $360 \mathrm{~nm}$. To evaluate the selectivity of this $\mathrm{N}$-doped $\mathrm{CD}$ toward $\mathrm{Fe}^{3+}$, interference assays were performed under identical conditions using above ions and $\mathrm{Fe}^{3+}$, and the $\mathrm{N}$-doped $\mathrm{CD}$ stock solution was added to different concentrations of $\mathrm{Fe}^{3+}$ solution in a similar manner.

\section{Results and Discussion}

3.1. Characterization of N-Doped CDs. The size and morphology of $\mathrm{N}$-doped CDs were characterized by HRTEM and AFM. The TEM image (Figure 1(a)) clearly revealed N-doped CDs with spherical morphology, average diameter (inset in Figure 1(a)) of $2.7 \mathrm{~nm}$, and a narrow particle size distribution of 2.3-3.3 nm. HRTEM images (Figure 1(b)) showed that the average lattice spacing of the $\mathrm{N}$-doped CDs was $0.32 \mathrm{~nm}$, in agreement with the (002) diffraction planes of graphite $[18,19]$. The AFM 3D image and topography image (Figures 2(a) and 2(b)) indicate that the N-doped CDs had a spherical shape, which is consistent with the TEM results. The average height (Figure 2(c)) of N-doped CDs was $3.16 \mathrm{~nm}$, which is close to the diameter of $\mathrm{N}$-doped CDs measured by TEM $(2.68 \mathrm{~nm})$. Hence, in accordance with the previous reports, the $\mathrm{N}$-doped CDs were almost spherical carbon nanoparticles [20, 21]. FT-IR spectroscopy and XPS analyses were performed to study the 


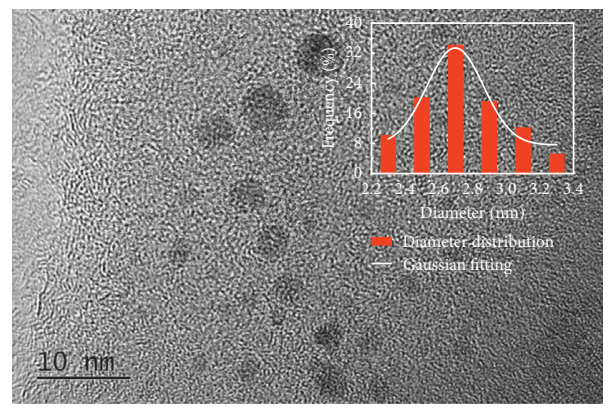

(a)

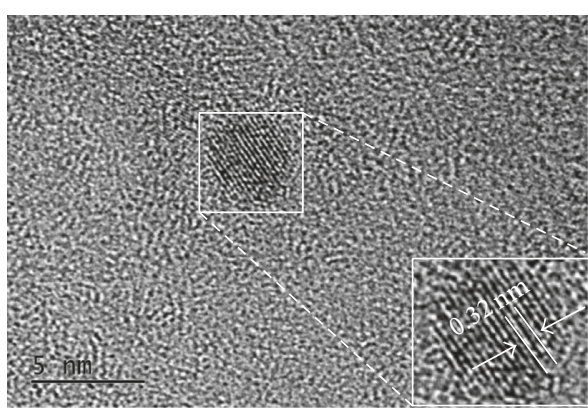

(b)

FIGURE 1: (a) TEM image of N-doped CDs. Inset shows the size distribution of N-doped CDs. (b) HRTEM reveals lattice spacing of N-doped CDs.

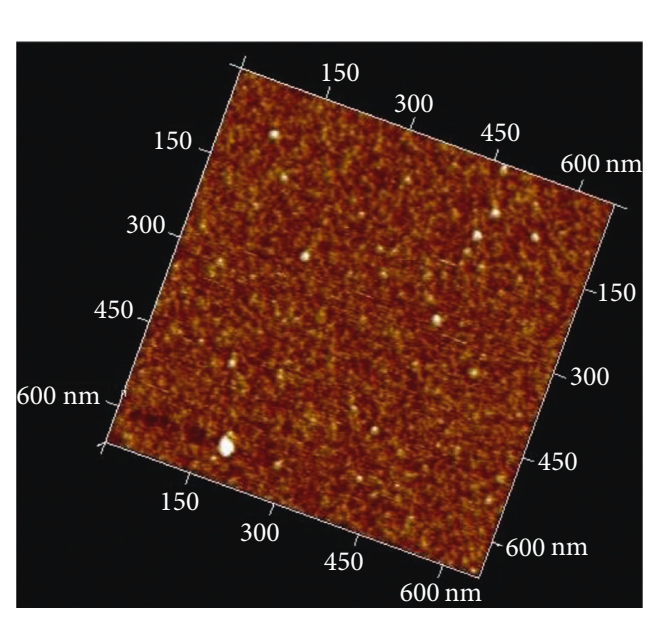

(a)

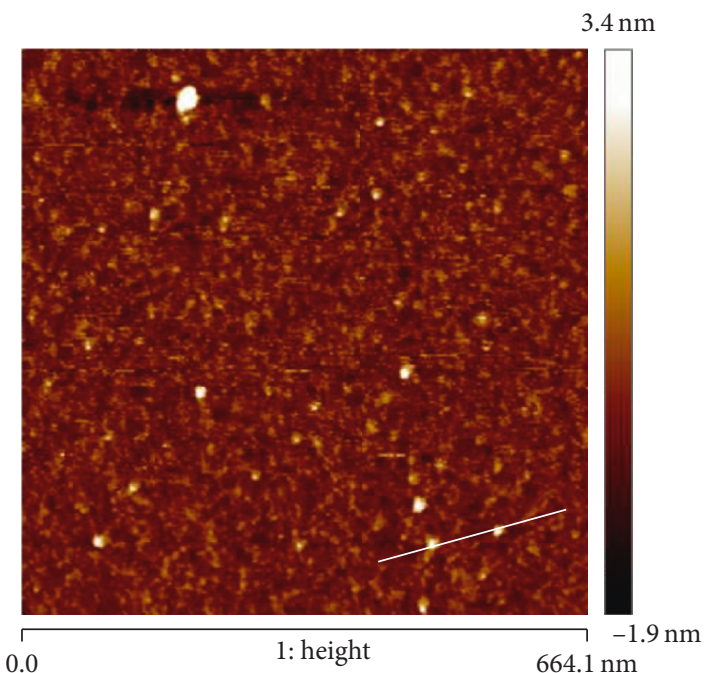

(b)

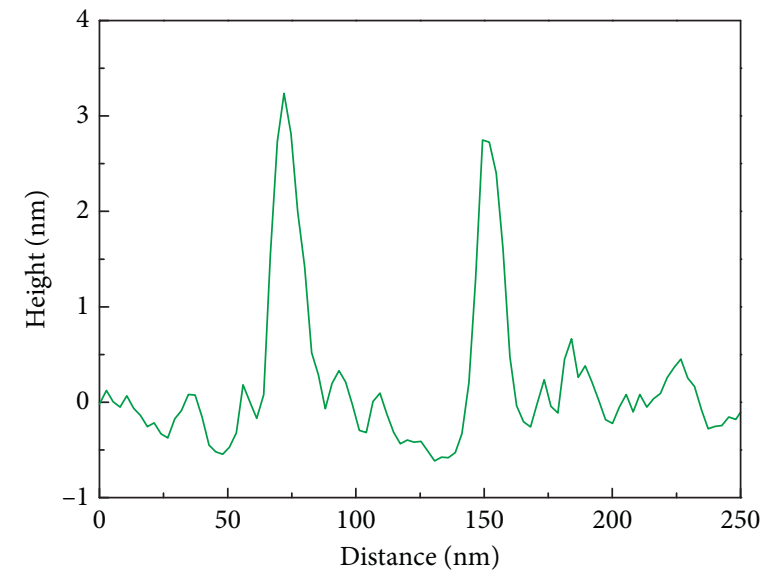

(c)

Figure 2: AMF images of N-doped CDs. (a) AMF 3D image, (b) AMF topography image, and (c) height profile along the line in (b).

chemical composition and functional groups of the $\mathrm{N}$-doped CDs. In the FT-IR spectrum in Figure 3(a), the peak at $3433 \mathrm{~cm}^{-1}$ is attributed to the stretching vibration of $-\mathrm{NH}$, the peaks at $1625 \mathrm{~cm}^{-1}$ indicate the existence of $\mathrm{C}=\mathrm{C}$, the peak at $1408 \mathrm{~cm}^{-1}$ was assigned to the bending vibration of $\mathrm{C}-\mathrm{NH}$ (indicating the successful adulteration of nitrogen atoms into the $\mathrm{C}$-dots), and the absorption at
$674 \mathrm{~cm}^{-1}$ is ascribed to C-H. These FT-IR assignments were further verified by XPS analysis. XPS was used to measure the surface chemical composition and elemental analysis of $\mathrm{N}$-doped CDs. The three main peaks at 284.78, 400.48, and $530.38 \mathrm{eV}$ of the XPS survey spectrum (shown in Figure 3(b)) correspond to $\mathrm{C} 1 \mathrm{~s}, \mathrm{~N} 1 \mathrm{~s}$, and $\mathrm{O} 1 \mathrm{~s}$, respectively. The $\mathrm{N}$-doped CDs contained 54.5 at.\% carbon, 19.2 at. \% nitrogen, and 26.3 


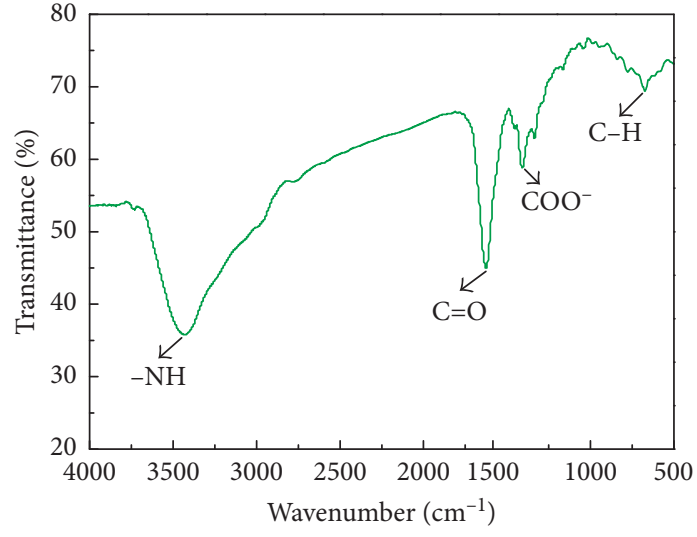

(a)

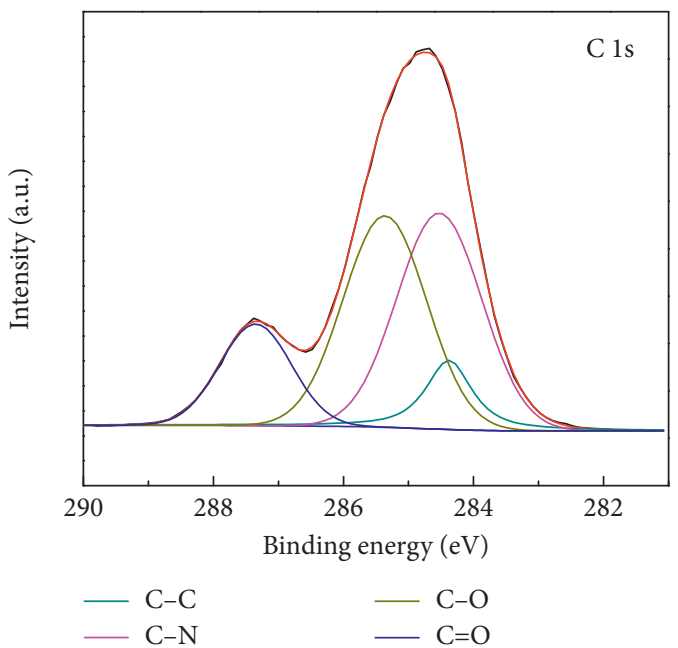

(c)

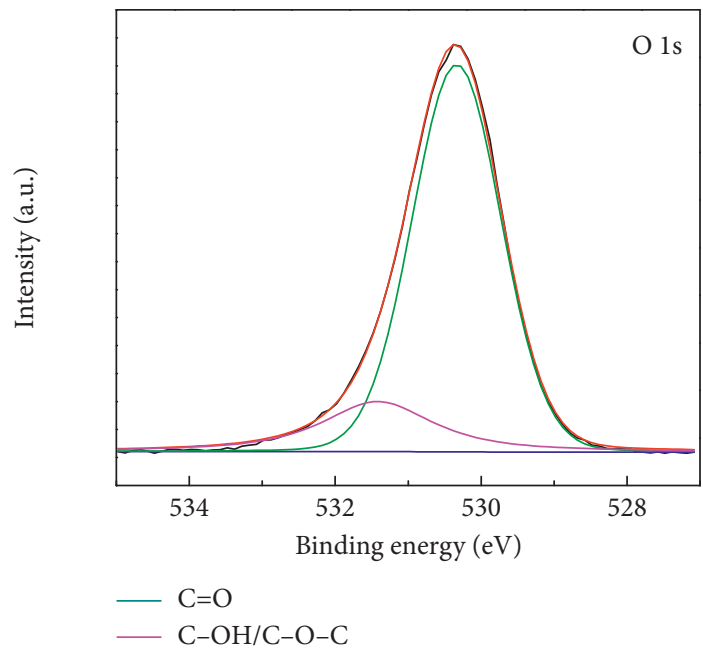

(e)

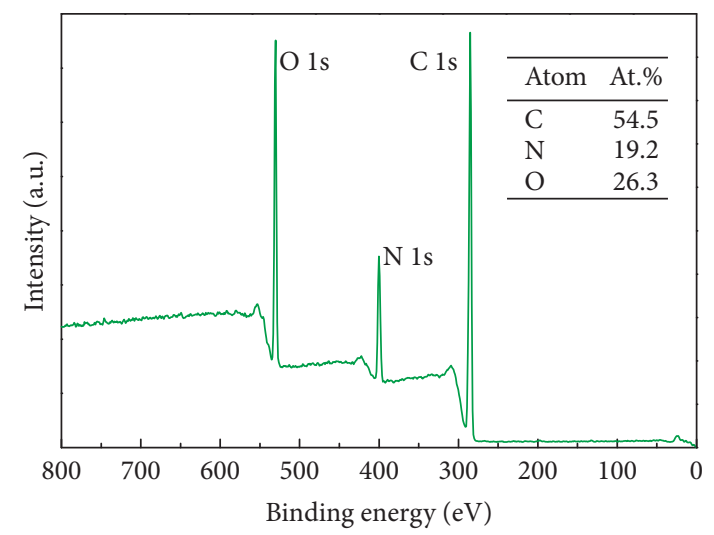

(b)

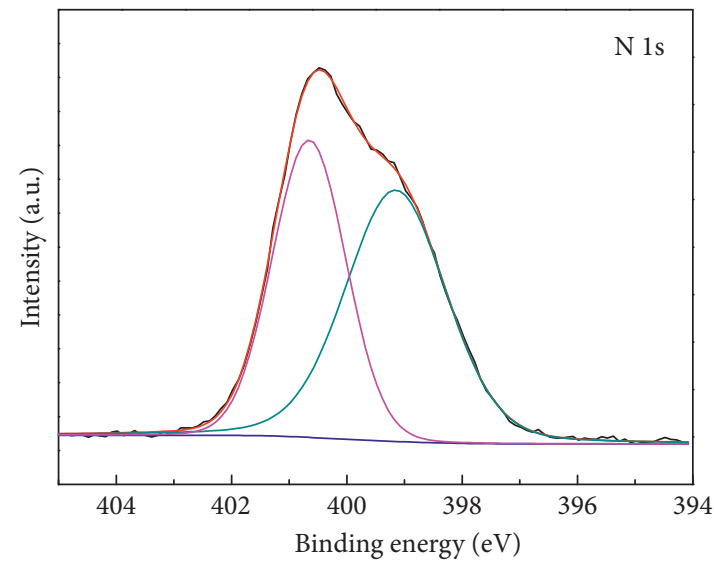

- $\mathrm{C}-\mathrm{N}-\mathrm{C}$

$-\mathrm{N}-\mathrm{H}$

(d)

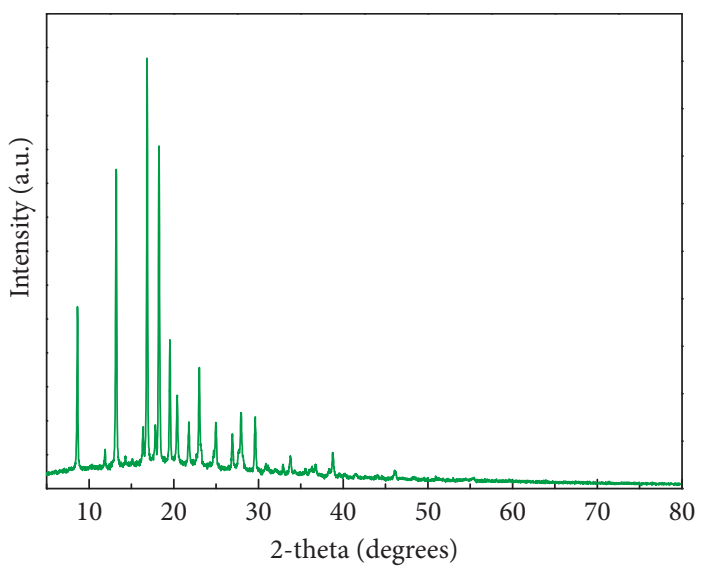

(f)

FIgURe 3: (a) FT-IR spectra of N-doped CDs. (b) XPS survey spectrum of N-doped CDs and high-resolution spectra of C1s (c), N1s (d), and O1s (e). (f) XRD pattern of N-doped CDs.

at. \% oxygen at the corresponding binding energies given in Figure 3(b). High-resolution XPS spectra of C1s (Figure 3(c)) can be ascribed to four component peaks with binding energies of about 284.38, 284.48, 285.38, and $287.38 \mathrm{eV}$. Here, the anterior peak located at $284.38 \mathrm{eV}$ reflects the bonding structure of $\mathrm{C}-\mathrm{C}\left(\mathrm{sp}^{3}\right)$ bonds, the peak located at $284.48 \mathrm{eV}$ reflects the bonding structure of the $\mathrm{C}-\mathrm{N}\left(\mathrm{sp}^{3}\right)$ bonds, and the peaks at 285.38 and $287.38 \mathrm{eV}$ are attributed to the $\mathrm{C}-\mathrm{O}\left(\mathrm{sp}^{2}\right)$ 


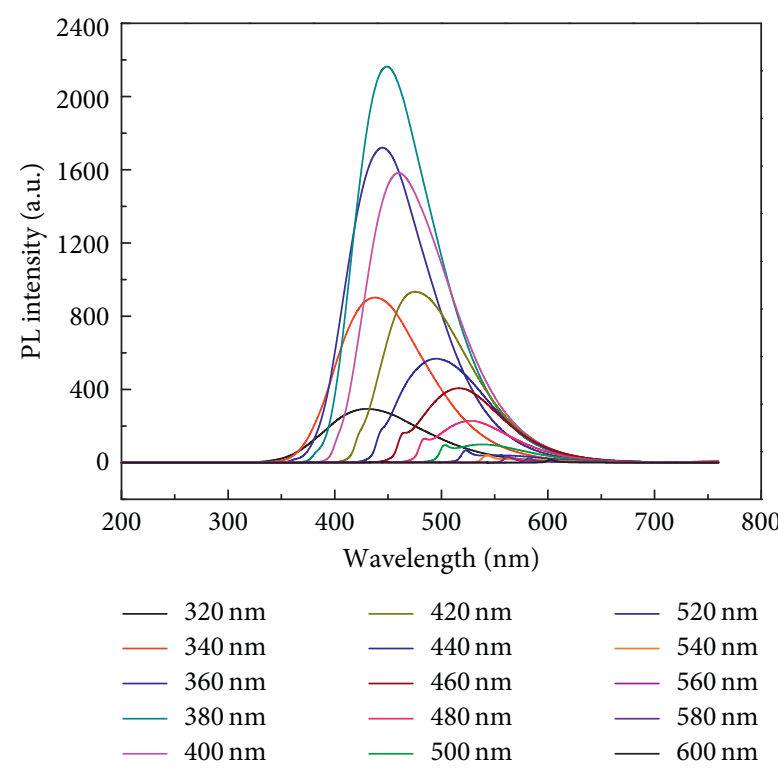

(a)

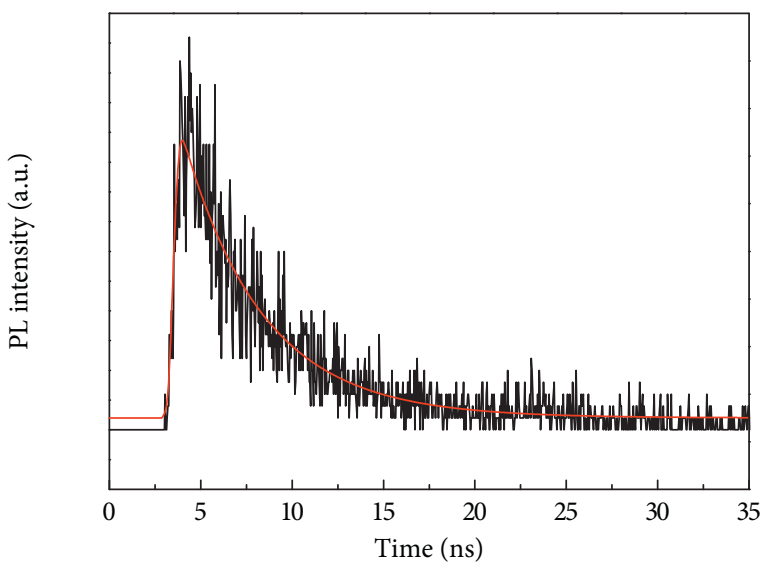

(c)

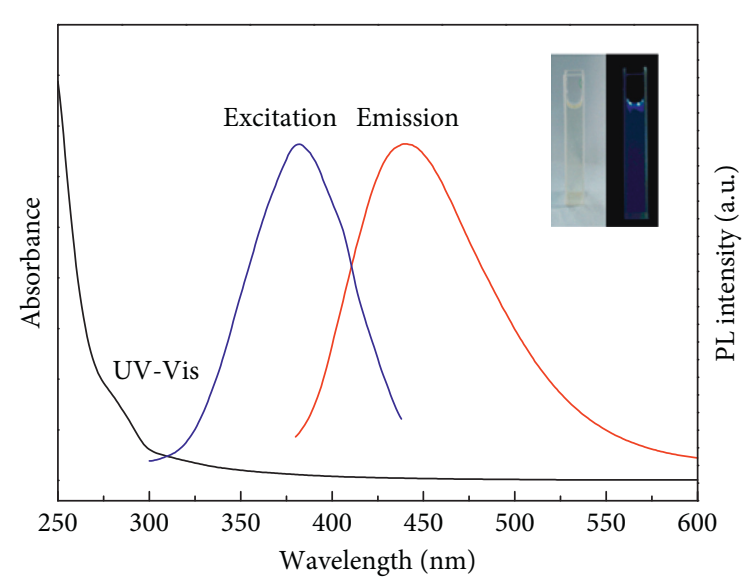

(b)

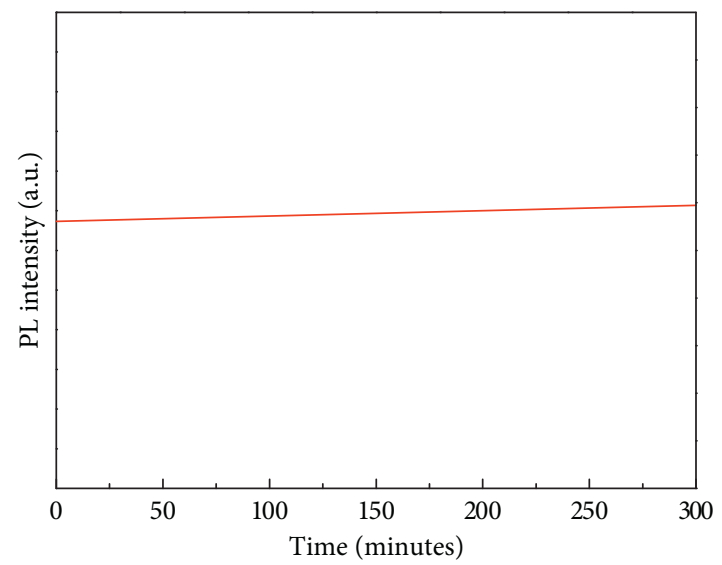

(d)

FIgURE 4: (a) UV-Vis absorption spectrum (black line), fluorescence excitation (red line, $\lambda_{\mathrm{em}}=438 \mathrm{~nm}$ ), and emission spectra (blue line, $\lambda_{\text {ex }}=377 \mathrm{~nm}$ ) of N-doped CDs. The insets show the photograph (left) and fluorescence image of N-doped CD solution under $365 \mathrm{~nm}$ UV light (right). (b) Fluorescence emission spectra of the N-doped CDs. (c) The fluorescence decay curve of N-doped CDs. (d) Fluorescence stability of N-doped CDs.

and $\mathrm{C}=\mathrm{O}\left(\mathrm{sp}^{2}\right)$ bonds, respectively [22]. This indicated that the as-prepared $\mathrm{N}$-doped $\mathrm{CDs}$ were rich in hydrophilic groups on their surfaces, which was consistent with the corresponding FT-IR spectrum. As shown in Figure 3(d) (partial XPS spectrum of N1s), the N1s peak can also be resolved into two components centred at 399.18 and $400.48 \mathrm{eV}$; the anterior peak located at $399.18 \mathrm{eV}$ reflects the bonding structure of $\mathrm{C}-\mathrm{N}-\mathrm{C}$ bonds, and the second peak located at $400.48 \mathrm{eV}$ reflects the bonding structure of the $\mathrm{N}-\mathrm{H}$ bonds $[23,24]$. The O1s peak had two components at 530.38 and $531.38 \mathrm{eV}$ for adsorbed oxygen: $\mathrm{C}=\mathrm{O}$ and $\mathrm{C}-\mathrm{OH} / \mathrm{C}-\mathrm{O}-\mathrm{C}$ (Figure 3(e)), respectively [21]. Surface functionality analyses via XPS are in agreement with FT-IR results. The above analysis indicated that the $\mathrm{N}$-doped $\mathrm{CDs}$ synthesized might have functional groups like $-\mathrm{COOH},-\mathrm{OH}$, and $-\mathrm{NH}$. XRD patterns (Figure 3 (f)) showed many narrow $2 \theta$ diffraction peaks at about $8.65^{\circ}$, $11.91^{\circ}, 13.21^{\circ}, 16.39^{\circ}, 16.86^{\circ}, 17.82^{\circ}, 18.27^{\circ}, 19.55^{\circ}, 20.41^{\circ}$, $21.79^{\circ}, 23.02^{\circ}, 24.73^{\circ}, 24.97^{\circ}, 26.93^{\circ}, 27.97^{\circ}, 29.62^{\circ}, 33.76^{\circ}$, and $38.75^{\circ}$, suggesting ordered carbon in N-doped CDs.

\subsection{Spectral Properties and Cytotoxicity Assay of N-Doped} CDs. As displayed in Figure 4(a), the excellent optical properties of the synthesized $\mathrm{N}$-doped CDs were demonstrated by absorption and PL spectroscopy. The N-doped CDs displayed broad UV-Vis absorption, which was attributed to the $n-\pi^{*}$ transition in $\mathrm{N}$-doped CDs. The emission wavelength of $\mathrm{N}$-doped $\mathrm{C}$-dots was red-shifted from 430 to $600 \mathrm{~nm}$ with excitation wavelength ranging from 320 to $600 \mathrm{~nm}$ [25]. In addition, the optimal excitation and emission wavelengths of the $\mathrm{N}$-doped $\mathrm{CDs}$ solution were located at 377 and $438 \mathrm{~nm}$ (Figure 4(b)). Separately, the $\mathrm{N}$-doped $\mathrm{CD}$ aqueous solution emitted strong blue light upon ultraviolet excitation at $365 \mathrm{~nm}$ (right inset, Figure 4(b)). 


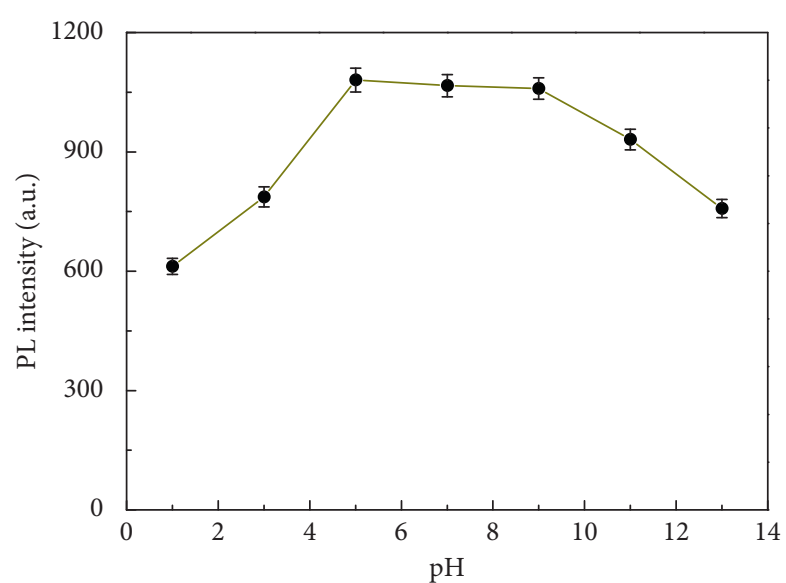

(a)

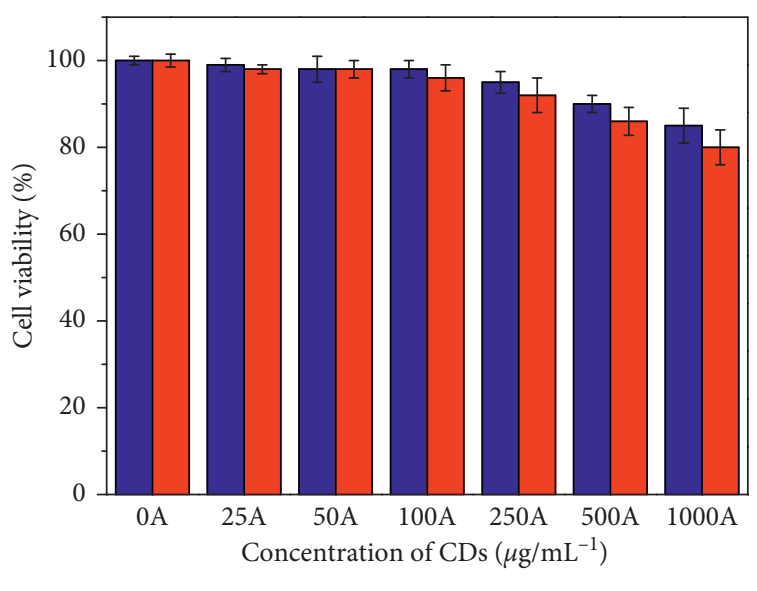

(b)

Figure 5: (a) PL spectra of N-doped CD aqueous solutions at different $\mathrm{pH}\left(\lambda_{\mathrm{ex}}=365 \mathrm{~nm}\right)$. (b) Cytotoxicity testing results via an MTT assay.

To further investigate the optical properties of the as-obtained $\mathrm{N}$-doped CDs, the PL excitation spectrum of the N-doped CDs was observed (Figure 4(b)). The spectrum displayed typical excitation wavelength dependence, and the emission wavelength was red-shifted when excited with longer wavelengths. This behaviour of the $\mathrm{N}$-doped CDs has been suggested to be a result of different sizes or the existence of different emissive sites on the surfaces [26]. This excitation-dependent emission property of carbon dots has also been found in the previous reports [27-29]. We further investigated the fluorescence stability of $\mathrm{N}$-doped CDs. Time-correlated single-photon counting (TCSPC) was applied to measure the fluorescence lifetime of the N-doped CDs. As presented in Figure 4(c), the decay lifetime of the $\mathrm{N}$-doped CDs was measured with the previous reports [30], and the calculated average fluorescence lifetime for the $\mathrm{N}$-doped CDs was $4.45 \pm 0.05 \mathrm{~ns}$. Moreover, the photostability (Figure $4(\mathrm{~d})$ ) of the N-doped CDs synthesized was tested upon continuous excitation at $360 \mathrm{~nm}$ for $5 \mathrm{~h}$; the fluorescence remained intact without any photobleaching, which corroborates to reasonably good photostability of N-doped CDs.

To investigate the applicability of $\mathrm{N}$-doped CDs as a fluorescence biomarker in a practical biological environment, the fluorescence stability of $\mathrm{N}$-doped CD aqueous solution was evaluated. As revealed in Figure 5(a), with increase in $\mathrm{pH}$ from 3.0 to 5.0, the fluorescence intensity reached a peak and decreased with $\mathrm{pH}$ ranging from 5.0 to 13.0. The original solution $\mathrm{pH}$ of the $\mathrm{N}$-doped CDs was approximately 9.0 . The figure shows that the fluorescence intensity of the $\mathrm{N}$-doped $\mathrm{CDs}$ at $\mathrm{pH} 7.0-9.0$ was stronger than that at 9.0 and the fluorescence intensity had not clearly declined at 7.0-9.0. A physiological environment generally has $\mathrm{pH}$ of 7.0-8.0, which is beneficial for bioimaging applications. In addition, fluorescence QY of the $\mathrm{N}$-doped CDs was found using quinine sulphate as standard (measured at $350 \mathrm{~nm}$ excitation wavelength, QY $=54 \%)$. The average QY of $\mathrm{N}$-doped CDs in aqueous solution at room temperature was $32.9 \%$. The high $\mathrm{QY}$ is possibly due to the existence of nitrogen-containing functional groups, which are generally excellent auxochromes and greatly enhance photoluminescence.

The biological application of $\mathrm{N}$-doped CDs was also explored. MTT assays were carried out to evaluate the cytotoxicity of the as-prepared N-doped CDs to living cells. As expected, cell viabilities were estimated to be greater than $90 \%$ upon addition of $\mathrm{N}$-doped CDs over a wide concentration range $(0-500 \mu \mathrm{g} / \mathrm{mL})$ and after incubation for $48 \mathrm{~h}$ (Figure 5(b)). High cell viabilities confirmed the low toxicity, excellent biocompatibility, and great potential of the asprepared $\mathrm{N}$-doped CDs for imaging in living cells. These also indicate that the as-prepared N-doped CDs can be considered safe for in vitro and in vivo applications.

\subsection{Application of $\mathrm{N}$-Doped $\mathrm{CDs}$}

3.3.1. Imaging of HeLa Cells. Based on these fluorescence properties, experiments were carried out to further demonstrate the availability of the as-prepared N-doped CDs for imaging in cells and plants. Figure 6 shows CLSM images under bright field, $405 \mathrm{~nm}, 458 \mathrm{~nm}$, and $514 \mathrm{~nm}$ excitations of HeLa cells incubated for $4 \mathrm{~h}$ at $37^{\circ} \mathrm{C}$ with 50,200,400, and $600 \mu \mathrm{g} \cdot \mathrm{mL}^{-1} \mathrm{~N}$-doped CDs. As shown in the figure, strong blue and green fluorescence of the HeLa cells can be seen at 405 and $488 \mathrm{~nm}$. More careful observation revealed that the luminescence spots appeared widely in the membrane and cytoplasmic areas of the HeLa cells. In addition, with the increase in the concentration of N-doped CDs, the fluorescence enhancement helped identify tumour cells. According to the previous studies, the cytoplasm-specific property of $\mathrm{N}$-doped CDs should be related to endocytosis $[1,9,14,21]$. The results indicated that $\mathrm{N}$-doped CDs could be used for in vitro tumour cell labelling via a simple incubation method.

3.3.2. Selectivity and Ratiometric Detection of $\mathrm{Fe}^{3+}$ in Serum. As shown in Figure 7(a), under the same conditions, in sharp contrast to $\mathrm{Fe}^{3+}$, other ions including $\mathrm{Hg}^{2+}, \mathrm{Cr}^{3+}, \mathrm{Fe}^{2+}, \mathrm{Co}^{2+}$, 

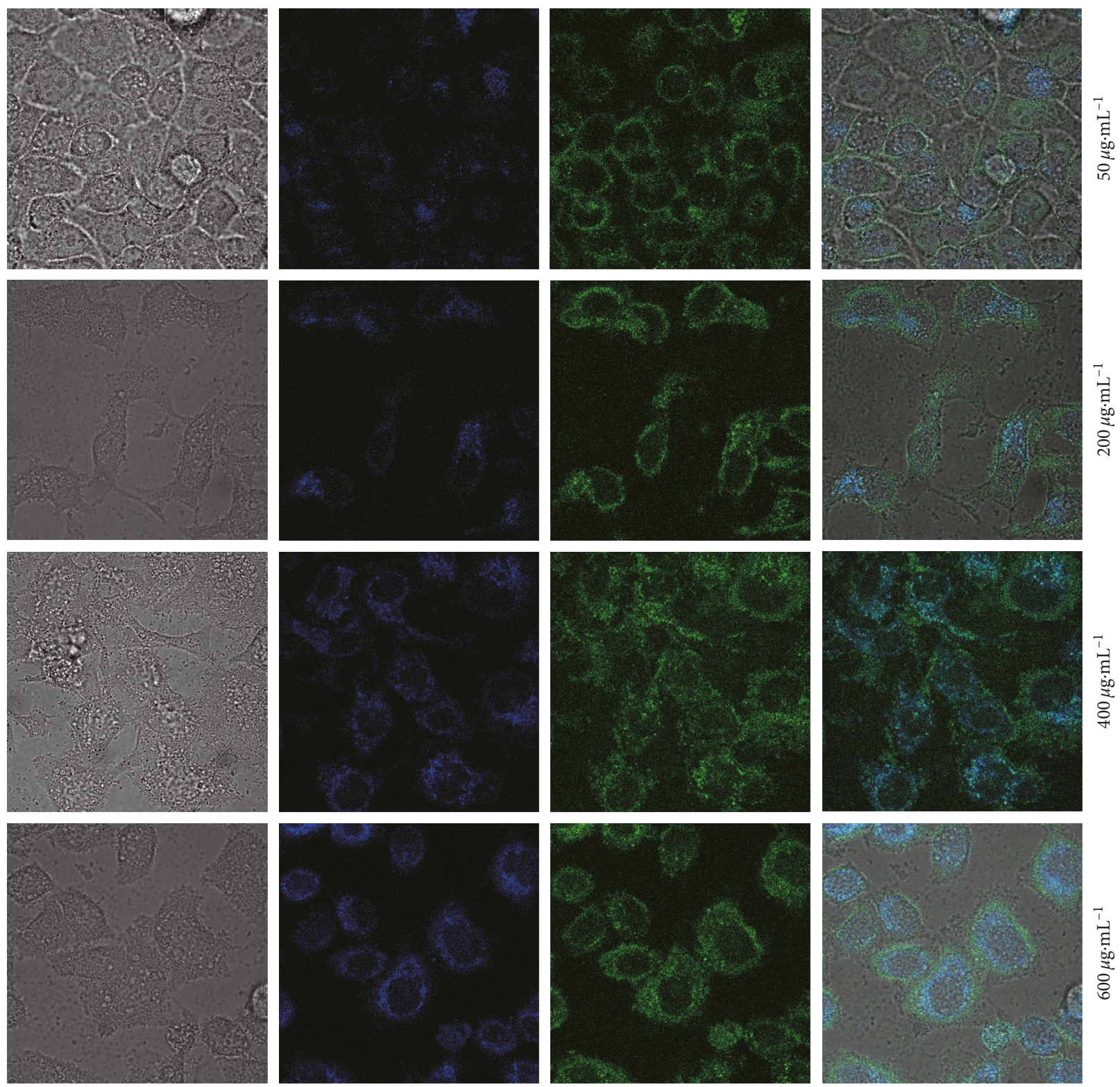

Figure 6: Laser scanning confocal microscopy images of HeLa cells with different concentrations of N-doped CDs.

$\mathrm{Cd}^{2+}, \mathrm{Sr}^{2+}, \mathrm{Al}^{3+}, \mathrm{Mg}^{2+}, \mathrm{Zn}^{2+}, \mathrm{Ca}^{2+}, \mathrm{K}^{+}, \mathrm{Na}^{+}$, and $\mathrm{Cu}^{2+}$ showed almost no influence on the spectra of the nanoprobe. The fluorescence could be quenched by $\mathrm{Fe}^{3+}$ ion due to the special coordination interaction between $\mathrm{Fe}^{3+}$ ion and the hydroxy groups on the surface of CDs, which may contribute to nonradiative electron transfer that involves partial transfer of an electron in the excited state to the d orbital of $\mathrm{Fe}^{3+}$. To further investigate the FL quenching mechanism of $\mathrm{N}$-doped CDs, different concentrations of $\mathrm{Fe}^{3+}$ solution were added to N-doped CD stock solution. As shown in Figure 7(b), the FL intensity of N-doped CDs gradually decreased with increasing $\mathrm{Fe}^{3+}$ concentration and the inset shows the relationship of the relative fluorescence intensity $F / F_{0}$ with $\mathrm{Fe}^{3+}$ concentration. Dynamic fluorescence quenching is described by the Stern-Volmer equation [31]. The inset in Figure 6(b) shows a linear relationship $\left(R^{2}=0.998\right)$ in the range of $\mathrm{Fe}^{3+}$ concentration from 0 to $50 \mu \mathrm{M}$. The detection limit was $37 \mathrm{nM}$ (signal-to-noise ratio of 3 ). The results demonstrated that $\mathrm{N}$-doped CDs show promise as a sensitive and selective probe for the detection of $\mathrm{Fe}^{3+}$. In order to demonstrate the analytical performance of the proposed $\mathrm{N}$-doped CDs in complicated biological samples, the capability of the $\mathrm{N}$-doped CDs was evaluated by quantitative detection of $\mathrm{Fe}^{3+}$ in human serum, and it was spiked with different concentrations of $\mathrm{Fe}^{3+}$ and measured by the proposed method. Table 1 shows that the recoveries were $95.2-112 \%$ with the relative standard deviation (RSD, $n=5$ ) less than $5.8 \%$, which indicates that the proposed method was sensitive and accurate.

\section{Conclusions}

We demonstrated a facile and green synthesis method to prepare novel fluorescent $\mathrm{N}$-doped CDs by hydrothermal reaction using amino acid L-citrulline as precursor. 


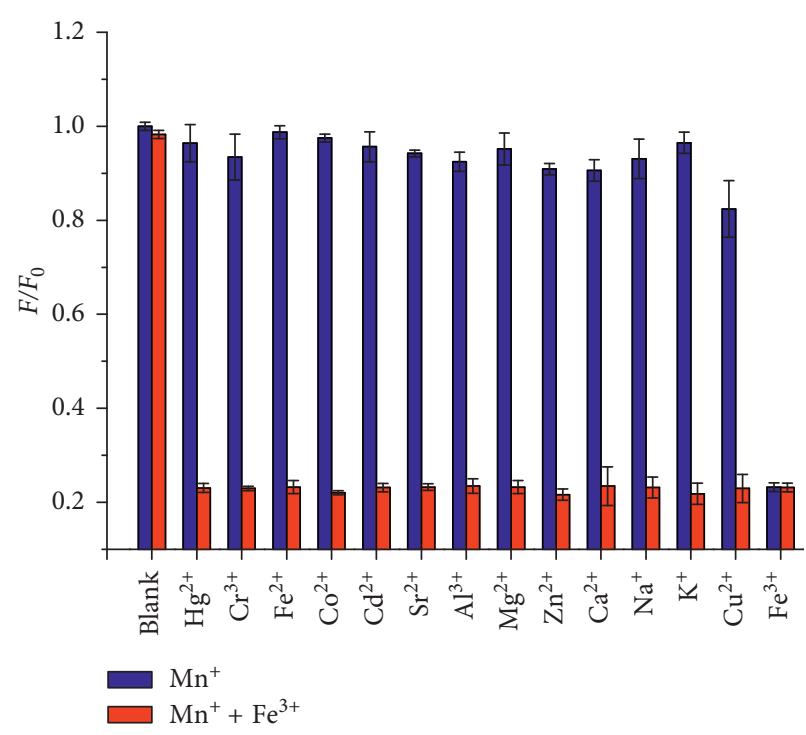

(a)

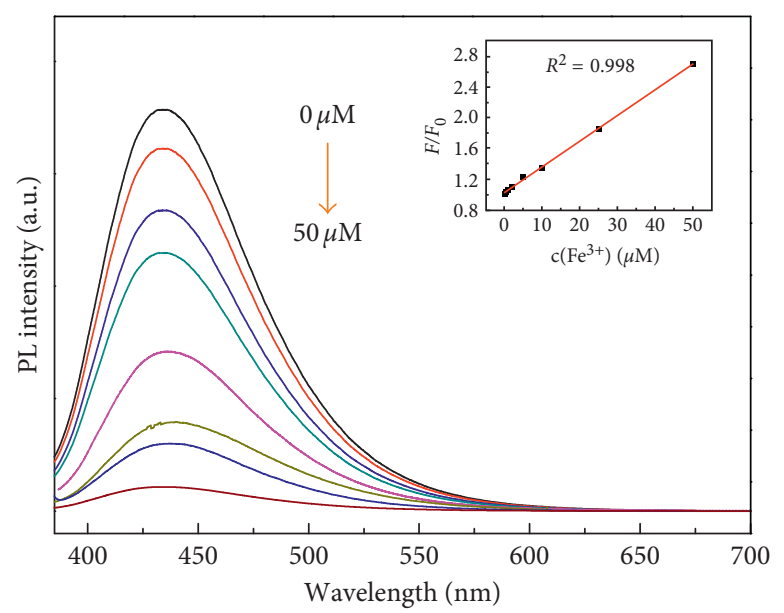

(b)

Figure 7: Ion detection of N-doped CDs. (a) Fluorescence recovery efficiency $F / F_{0}$ response of the N-doped CDs toward Fe ${ }^{3+}$ and other interference. (b) PL spectra of $\mathrm{N}$-doped CDs with different $\mathrm{Fe}^{3+}$ concentrations ( 0 to $50 \mu \mathrm{M}$ ). Inset: the dependence of $F / F_{0}$ on concentration (0 to $50 \mu \mathrm{M})$.

TABLe 1: Determination of iron in human serum using N-doped CDs.

\begin{tabular}{lcccc}
\hline Samples & Added $(\mu \mathrm{mol} / \mathrm{L})$ & Found $(\mu \mathrm{mol} / \mathrm{L})$ & Recovery $(\%)$ & RSD $\%(n=5)$ \\
\hline \multirow{3}{*}{ Serum } & 0.250 & 0.281 & 112 & 5.8 \\
& 2.50 & 2.61 & 104 & 4.6 \\
& 25.0 & 23.8 & 95.2 & 3.9 \\
\hline
\end{tabular}

The N-doped CD aqueous solution emitted strong blue light under UV irradiation with a fluorescence quantum yield of $32.9 \%$, and the emission wavelength was red-shifted under excitation with longer wavelengths. The fluorescent $\mathrm{N}$-doped CDs acted as novel fluorescence probes that facilitated simultaneous imaging of HeLa cells and sensitivity detection of $\mathrm{Fe}^{3+}$ ions. The $\mathrm{N}$-doped CDs showed outstanding overall performance such as outstanding optical properties, good chemical and photochemical stability, inertness to interference of metal ions and biomolecular species, and excellent biocompatibility, which make N-doped CDs a desirable alternative probe for biological imaging, detection, and many other applications.

\section{Data Availability}

The data used to support the findings of this study are included within the article, and any further information is available from the corresponding author upon request.

\section{Conflicts of Interest}

The authors declare that there are no conflicts of interest regarding the publication of this paper.

\section{Acknowledgments}

This work was supported by the National Natural Science Foundation of China (no. 21505115), the Science and
Technology Foundation of the Guizhou Province, Science and Technology Department (nos. LH20147406 and LH20167034), the Natural Science Foundation of the Guizhou Province, Education Department (no. KY(2017)368), the Social Development Foundation of the Science and Technology Bureau of Qianxinan Prefecture (no. 2016-1-29), and the Ph.D. Programs Foundation of Xingyi Normal University for Nationalities (no. 16XYBS20).

\section{References}

[1] Y. W. Zheng, D. Yang, X. Wu et al., "A facile approach for the synthesis of highly luminescent carbon dots using vitaminbased small organic molecules with benzene ring structure as precursors," RSC Advances, vol. 5, no. 110, pp. 90245-90254, 2015.

[2] V. Georgakilas, J. A. Perman, J. Tucek, and R. Zboril, "Broad family of carbon nanoallotropes: classification, chemistry, and applications of fullerenes, carbon dots, nanotubes, graphene, nanodiamonds, and combined superstructures," Chemical Reviews, vol. 115, no. 11, pp. 4744-4822, 2015.

[3] M. J. Meziani, X. L. Dong, L. Zhu et al., "Visible-light-activated bactericidal functions of carbon "quantum" dots," ACS Applied Materials and Interfaces, vol. 8, no. 17, pp. 10761-10766, 2016.

[4] S. Mandani, D. Dey, B. Sharma, and T. K Sarma, "Natural occurrence of fluorescent carbon dots in honey," Carbon, vol. 119, no. 9, pp. 569-572, 2017.

[5] S. Li, Z. Guo, Y. Zhang, W. Xue, and Z. H. Liu, "Blood compatibility evaluations of fluorescent carbon dots," ACS 
Applied Materials and Interfaces, vol. 7, no. 34, pp. 1915319162, 2015.

[6] H. Ding, S. B. Yu, J. S. Wei, and H. M. Xiong, "Full-color lightemitting carbon dots with a surface-state-controlled luminescence mechanism," ACS Nano, vol. 10, no. 1, pp. 484-491, 2016.

[7] H. Li, W. Q. Kong, J. Liu et al., "Fluorescent N-doped carbon dots for both cellular imaging and highly-sensitive catechol detection," Carbon, vol. 91, no. 11, pp. 66-475, 2015.

[8] L. Liu, L. Chen, J. G. Liang, L. Z. Liu, and H. Y. Han, "A novel ratiometric probe based on nitrogen-doped carbon dots and rhodamine $\mathrm{b}$ isothiocyanate for detection of $\mathrm{Fe}^{+}$in aqueous solution," Journal of Analytical Methods in Chemistry, vol. 2016, Article ID 4939582, 7 pages, 2016.

[9] S. Y. Lim, W. Shen, and Z. Q. Gao, "Carbon quantum dots and their applications," Chemical Society Reviews, vol. 44, no. 1, pp. 362-381, 2015.

[10] Y. B. Song, S. J. Zhu, S. Y. Xiang et al., "Investigation into the fluorescence quenching behaviors and applications of carbon dots," Nanoscale, vol. 6, no. 9, pp. 4676-4682, 2014.

[11] J. J. Zhao, M. J. Huang, L. L. Zhang et al., "A unique approach to develop carbon dot-based nanohybrid near-infrared ratiometric fluorescent sensor for the detection of mercury ions," Analytical Chemistry, vol. 89, no. 15, pp. 8044-8049, 2017.

[12] K. Jiang, S. Sun, L. Zhang, Y. H. Wang, C. Z. Cai, and H. W. Lin, "Bright-yellow-emissive N-doped carbon dots: preparation, cellular imaging, and bifunctional sensing," ACS Applied Materials and Interfaces, vol. 7, no. 41, pp. 2323123238, 2015.

[13] X. J. Gong, W. J. Lu, Y. Liu et al., "Low temperature synthesis of phosphorous and nitrogen co-doped yellow fluorescent carbon dots for sensors and bioimaging," Journal of Materials Chemistry B, vol. 3, no. 33, pp. 6813-6819, 2015.

[14] X. X. Chen, Q. Q. Jin, L. Z. Wu, C. H. Tung, and X. J. Tang, "Synthesis and unique photoluminescence properties of nitrogen-rich quantum dots and their applications," Angewandte Chemie International Edition, vol. 53, no. 51, pp. 14447-14450, 2014.

[15] P.F. Lv, Y.X. Yao, H. M Zhou et al., "Synthesis of novel nitrogendoped carbon dots for highly selective detection of iron ion," Nanotechnology, vol. 28, no. 12, pp. 165502-165511, 2017.

[16] L. Wang and H. S. Zhou, "Green synthesis of luminescent nitrogen-doped carbon dots from milk and its imaging application," Analytical Chemistry, vol. 86, no. 15, pp. 89028905, 2014.

[17] P. C. Hsu and H. T. Chang, "Synthesis of high-quality carbon nanodots from hydrophilic compounds: role of functional groups," Chemical Communications, vol. 48, no. 33, pp. 3984-3986, 2012.

[18] Z. H. Kang, E. B. Wang, B. D. Mao et al., "Controllable fabrication of carbon nanotube and nanobelt with a polyoxometalateassisted mild hydrothermal process," Journal of the American Chemical Society, vol. 127, no. 18, pp. 6534-6535, 2005.

[19] J. Lu, J. X. Yang, J. Z. Wang, A. L. Lim, S. Wang, and K. P. Loh, "One-pot synthesis of fluorescent carbon nanoribbons, nanoparticles, and graphene by the exfoliation of graphite in ionic liquids," ACS Nano, vol. 3, no. 8, pp. 2367-2375, 2009.

[20] N. Li, A. Than, C. C. Sun et al., "Monitoring dynamic cellular redox homeostasis using fluorescence-switchable graphene quantum dots," ACS Nano, vol. 10, no. 12, pp. 11475-11482, 2016.

[21] L. Yang, W. H. Jiang, L. P. Qiu et al., "One pot synthesis of high quantum yield of polyethylene glycol anchored carbon dots and functionalized with nuclear localization signal peptide for cell nucleus imaging," Nanoscale, vol. 7, no. 14, pp. 6104-6113, 2015.

[22] X. Q. Niu, G. S. Liu, L. Y. Li, Z. Fu, H. Xu, and F. L. Cui, "Green and economical synthesis of nitrogen-doped carbon dots from vegetables for sensing and imaging applications," RSC Advances, vol. 5, no. 115, pp. 95223-95229, 2015.

[23] J. Ju and W. Chen, "Synthesis of highly fluorescent nitrogendoped graphene quantum dots for sensitive, label-free detection of Fe (III) in aqueous media," Biosensors and Bioelectronics, vol. 58, no. 8, pp. 219-225, 2014.

[24] X. W. Dong, Y. J. Su, H. J. Geng et al., "Fast one-step synthesis of N-doped carbon dots by pyrolyzing ethanolamine," Journal of Materials Chemistry C, vol. 2, no. 36, pp. 7477-7481, 2014.

[25] H. J. Zhang, Y. L. Chen, M. J. Liang et al., "Solid-phase synthesis of highly fluorescent nitrogen-doped carbon dots for sensitive and selective probing ferric ions in living cells," Analytical Chemistry, vol. 86, no. 19, pp. 9846-9852, 2014.

[26] Y. Q. Dong, H. C. Pang, H. B. Yang et al., "Carbon-based dots co-doped with nitrogen and sulfur for high quantum yield and excitation-independent emission," Angewandte Chemie International Edition, vol. 52, no. 30, pp. 7800-7804, 2013.

[27] L. Y. Zhang, D. H. Wang, H. W. Huang et al., "Preparation of gold-carbon dots and ratiometric fluorescence cellular imaging," ACS Applied Materials and Interfaces, vol. 8, no. 10, pp. 6646-6655, 2016.

[28] A. M. Alam, B. Y. Park, Z. K. Ghouri, M. Park, and H. Y. Kim, "Synthesis of carbon quantum dots from cabbage with downand up-conversion photoluminescence properties: excellent imaging agent for biomedical applications," Green Chemistry, vol. 17, no. 7, pp. 3791-3797, 2015.

[29] J. Hou, J. Yan, Q. Zhao, Y. Li, H. Ding, and L. Ding, "A novel one-pot route for large-scale preparation of highly photoluminescent carbon quantum dots powders," Nanoscale, vol. 5, no. 20, pp. 9558-9561, 2013.

[30] J. C. Shen, Q. Li, Y. Zhang, X. J. She, C. F. Wang, and S. Chen, "Nitrogen-doped carbon dots derived from polyamindoamine dendrimer," RSC Advances, vol. 6, no. 64, pp. 5970259707, 2016.

[31] S. Mohapatra, S. Sahu, N. Sinha, and S. K. Bhutia, "Synthesis of carbon dot based photoluminescent probe for selective and ultrasensitive detection of $\mathrm{Hg}^{+}$in water and living cells," Analyst, vol. 140, no. 4, pp. 1221-1228, 2015. 

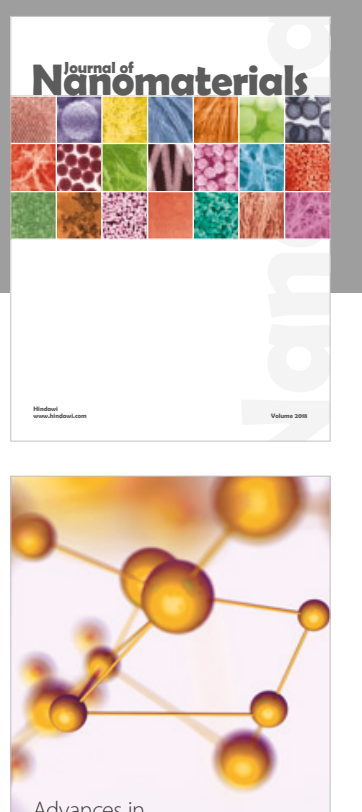

Physical Chemistry
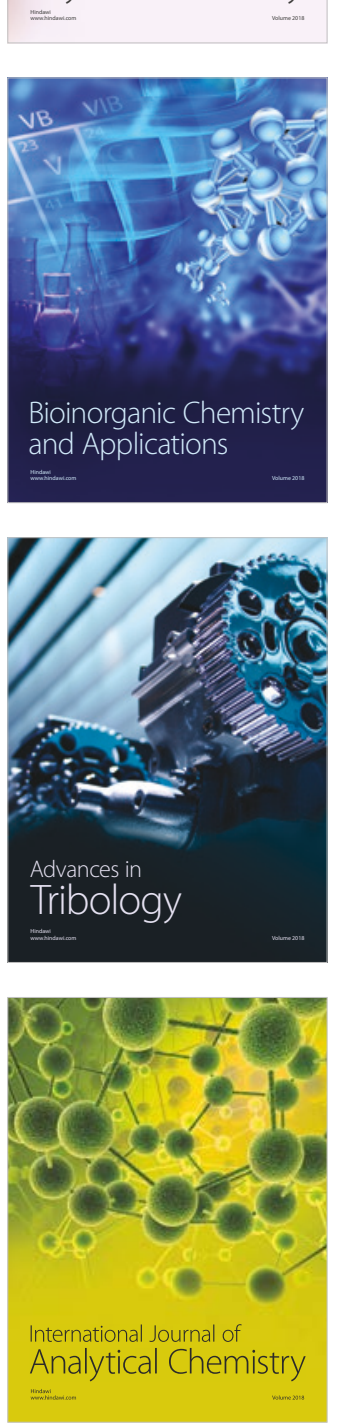

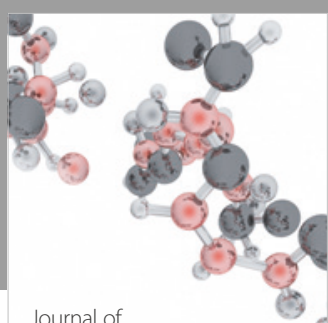

Analytical Methods

in Chemistry

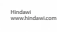

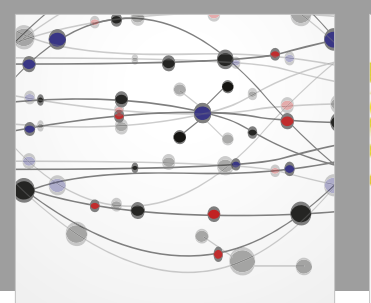

The Scientific World Journal

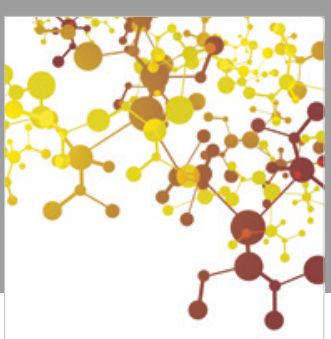

Journal of

Applied Chemistry
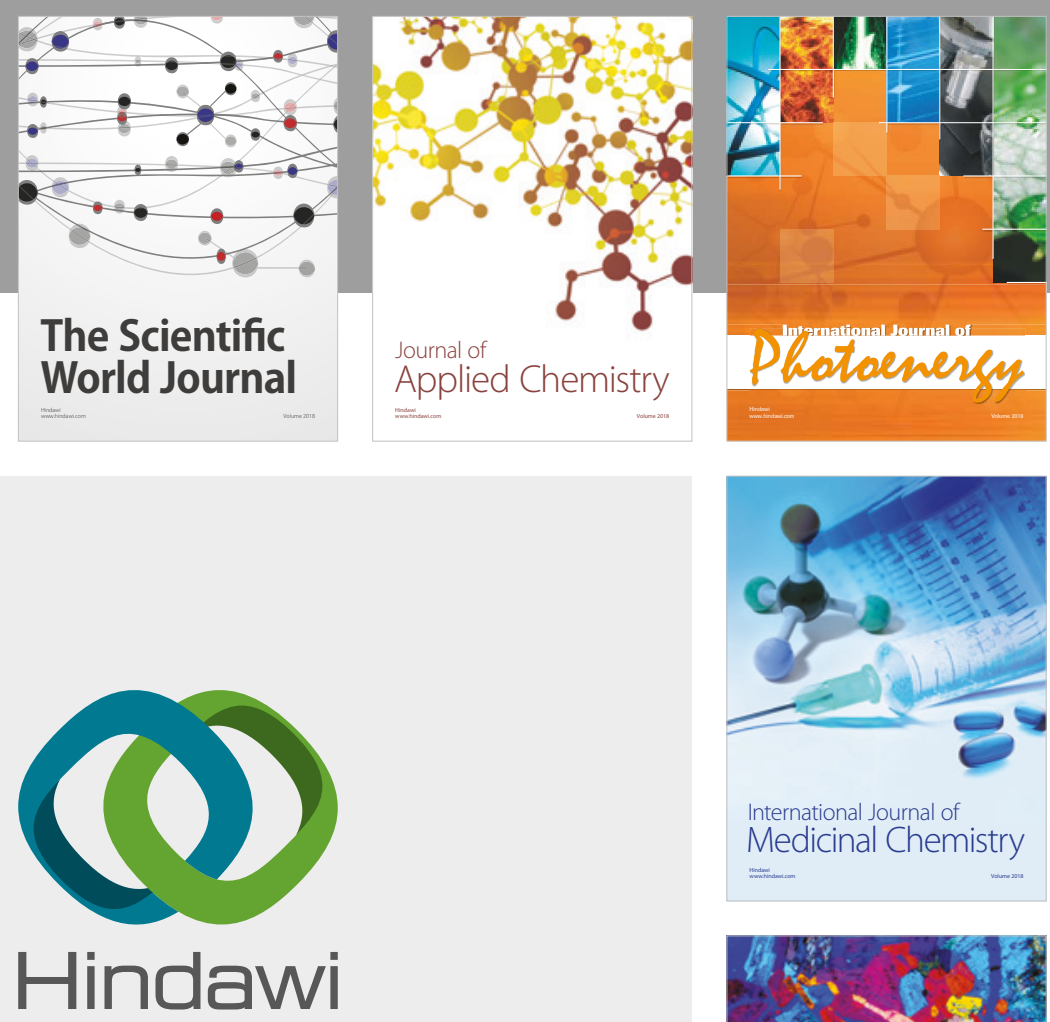

Submit your manuscripts at

www.hindawi.com
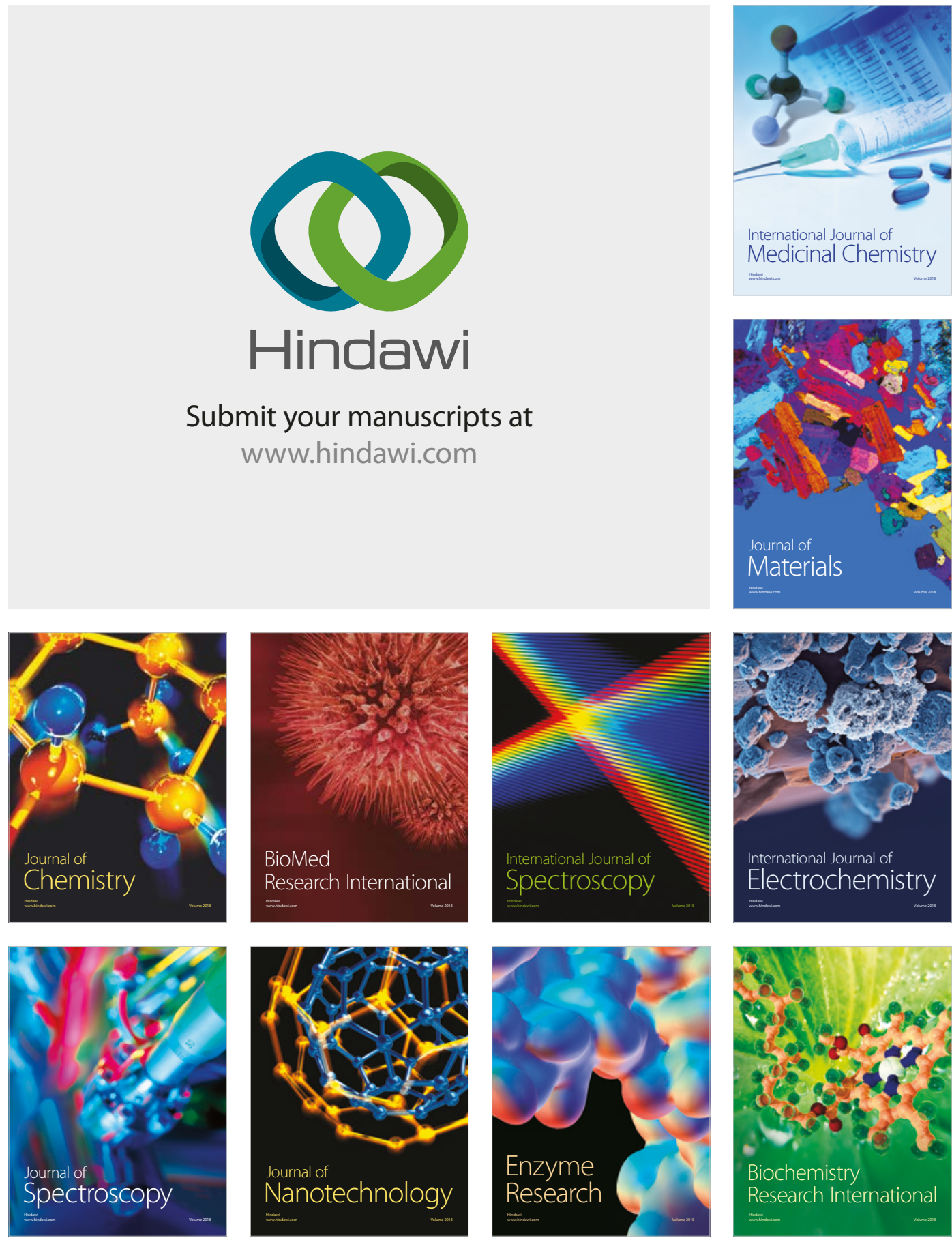
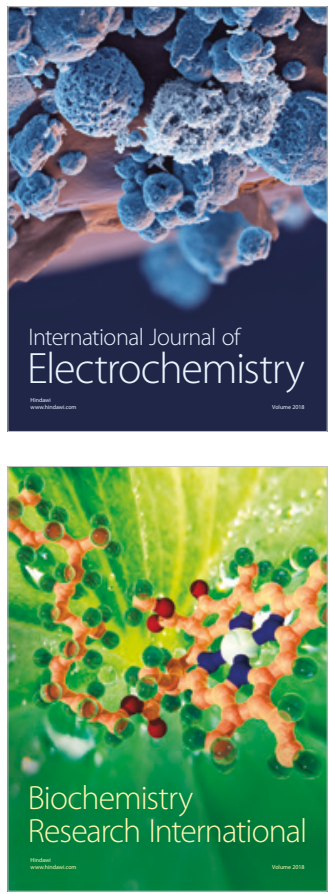